\title{
THE EFFECT OF TILLAGE SIMPLIFICATIONS AND MINERAL FERTILISATION LEVEL ON THE NUMBER AND DISTRIBUTION OF WEED SEEDS IN SOIL
}

\author{
Karol Bujak, Mariusz Frant, Bożenna Budzyńska \\ Department of Soil and Plant Cultivation, University of Life Sciences in Lublin, Akademicka 13, 20-950 Lublin, Poland \\ e-mail: em.frant@poczta.pl
}

Received: 11.03.2008

S u m m a r y

In the present paper, results of a study on the effect of a reduction in the number of ploughings in a crop rotation on the seed weed bank in the soil are presented. The study was carried out in the second and fourth year of a crop rotation (potatospring wheat- pea- winter wheat). A reduction in the number of ploughings to three in the crop rotation decreased weed infestation of the plough layer, whereas when only one ploughing was made there was clearly more weed diaspores in the soil than after plough tillage. In the first period of the study, the mineral fertilisation level did not differentiate the weed seed bank in the soil, whereas after the end of the rotation its significant increase was noted as a result of more intensive fertilisation. In all the experimental treatments, diaspores of Chenopodium album, Viola arvensis, Galinsoga sp. and Apera spica-venti occurred in greatest numbers.

Key words: crop rotation, tillage, weeds, weed seed bank

\section{INTRODUCTION}

In connection with the need to limit production costs in agriculture, different simplifications in soil tillage are used. They consist most frequently in reducing the depth and frequency of ploughings, replacing them by other less energy-consuming treatments, including direct sowing. R a de cki, 1986; D zi en i a and Sosnowski, 1991; (Gawrońska-Kulesza, 1997; Malicki et al. 1997; Kordas, 1999). The use of such simplifications may however lead to an increase in weed infestation of a crop canopy and accumulation of weed diaspores in the soil ( $\mathrm{Dw}$ o r a k, 1987; Papay et al. 1994; Skrzypczak et al. 1995); F e ld man et al. 1996; Wit k ow ski, 1998; Dorado et al. 1999; Dzienia et al. 2003. Nevertheless, studies conducted so far do not give a full and unequivocal answer to the question how different plough tillage simplifications affect possible weed infestation of soil. Therefore, this study was conducted; its aim was to determine the condition and level of weed infestation of the cultivated soil layer under the influence of a reduced number of ploughings in a fourfield crop rotation system and with differentiated mineral fertilisation levels.

\section{MATERIALS AND METHODS}

The field experiment was carried out in the years 1998-2002 at the Czesławice Experimental Farm, belonging to the University of Natural Sciences in Lublin. The field experiment was set up in a splitblock design, with four replications, on grey-brown podzolic soil formed from loess with the granulometric composition of clayey silt ( $36 \%$ of fine particles). The soil in the experiment was characterised by a slightly acid reaction ( $\mathrm{pH}$ in $1 \mathrm{~mol} \mathrm{KCl \times \textrm {dm } ^ { - 3 }}$ - 6.5-6.6), humus

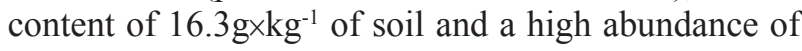
available phosphorus, potassium and magnesium.

The field studies covered the first rotation of the four-field crop rotation beginning with the following crop sequencing of all the plants: potato-spring wheatpea - winter wheat. For each plant, three tillage methods and two mineral fertilisation levels were used:

I. Tillage methods

A - traditional (7 ploughings per rotation),

$\mathrm{B}-$ reduced (3 ploughings per rotation),

$\mathrm{C}$ - reduced (1 ploughing per rotation);

II. Mineral fertilisation levels

a. $167.5 \mathrm{~kg}$ NPK and b. $251.2 \mathrm{~kg}$ NPK on an annual average basis per rotation.

Ploughings were replaced mainly by soil cultivating or disking. A detailed list of measures performed in particular tillage treatments is shown in Table 1.

The following herbicides were applied in particular crop plants: in potato - Dispersion Afalon 450SC 
$2 \mathrm{~L} \times \mathrm{ha}^{-1}$ (450 $\mathrm{g}$ of linuron in 1L of the herbicide); in spring wheat - Puma Uniwersal 069 EW -1Lxha-1 (69 g of fenoxaprop-P-ethyl with a $75 \mathrm{~g}$ addition of mefenpyr-diethyl in $1 \mathrm{~L}$ of the herbicide) and Aminopielik D $450 \mathrm{SL}^{-3}{\mathrm{~L} \times h a^{-1}}$ (417.5 $\mathrm{g} 2.4 \mathrm{D}, 32.5 \mathrm{~g}$ of dicamba in the form of dimethylamine salts in $1 \mathrm{~L}$ of the herbicide); in pea - Stomp 330EC $4{\mathrm{~L} \times h a^{-1}}$ (330g of pendimethalin in $1 \mathrm{~L}$ of the herbicide); in winter wheat - Puma Uniwersal $069 \mathrm{EW}-1.2{\mathrm{~L} \times h \mathrm{~h}^{-1}}^{2}$ (69g of fenoxaprop-P-ethyl with a $75 \mathrm{~g}$ addition of mefenpyr-diethyl in $1 \mathrm{~L}$ of the herbicide) and Aminopielik D 450SL - $3{\mathrm{~L} \times h a^{-1}}$ (417.5 g $2.4 \mathrm{D}, 32.5 \mathrm{~g}$ of dicamba in the form of dimethylamine salts in $1 \mathrm{~L}$ of the herbicide).

Soil samples collected using a cylinder with a diameter of $7.8 \mathrm{~cm}$ from three soil layers, notably: 0-5 cm, 5-15 cm and $15-30 \mathrm{~cm}$, after the harvesting of particular plants, were the object of detailed examination. The soil samples for each treatment were a mixed sample from the replications of each tillage method for particular plants of the crop rotation. In order to separate weed seeds from soil solid particles, the samples were washed with water on sieves with $0.25 \mathrm{~mm}$ mesh. They were then dried at a temperature of $40^{\circ} \mathrm{C}$ and weed fruits and seeds were picked out manually (using forceps) from them. In this study, only properly developed and filled weed fruits and seeds, hence presumably able to germinate, were taken into consideration. Species names of weed seeds followed M ir e k et al. [1995].

\section{RESULTS AND DISCUSSION}

The study conducted in the years 2000 and 2002 (in the second and fourth year of the crop rotation) showed that the applied tillage simplifications and mineral fertilisation level had no significant effect on the species composition of weed seeds in the 0-30 $\mathrm{cm}$ soil layer (Tab. 2 and 3). The determinations made after the end of the rotation only demonstrated substantial impoverishment of the species composition of weed diaspores (Tab. 3). From among previously noted species, seeds of Fallopia convolvulus, Sonchus asper, Vicia tetrasperma, Thlaspi arvense, Myosotis arvensis and Polygonum persicaria were not found, and caryopses of Avena fatua, which had not been previously noted, were determined. In both years of the study, irrespective of the tillage method, slightly more weed species were noted in the intensively fertilised treatments. A significant decrease in the number of weed diaspores in the soil in 2002 compared to 2000 is also worth noting.

The applied tillage modifications significantly differentiated the seed weed bank in the soil (Tab. 4). In both years of the study, the smallest number of weed seeds, both the total number and the number of dominant species' seeds, was found after the number of ploughings was reduced to 3 in the crop rotation (B), it was significantly larger after typical tillage (A - 7 ploughings in the crop rotation), and the largest one when only one ploughing was made in the crop rotation $(\mathrm{C})$.

More intensive fertilisation increased significantly the total weed seed bank and the number of dominant species' seeds only in 2002, thus, after the end of the crop rotation (Tab. 4). In the present study, no significant interaction was found between the tillage system and the fertilisation level with respect to the weed seed bank in the soil.

Also, the applied tillage simplifications and mineral fertilisation level had no significant impact on the distribution of weed seeds in the analysed soil layers. Only the smallest number of diaspores in the surface layer was noted most frequently, and its increase together with the increase of the depth.

The species composition of weeds in particular experimental treatments was similar. In 2000 only 8 species from the weed species found occurred in all the tillage and fertilisation treatments. But in 2002 as many as 12 species were common out of 18 species found. The dominant species were as follows: Chenopodium album, Viola arvensis, Apera spica-venti and Galinsoga sp. Chenopodium album seeds occurred in greatest numbers among them. They accounted for $60 \%$ of the total number of all identified diaspores.

To sum up the obtained results, it should be stressed that the introduced simplifications did not have an unequivocal effect on the weed seed bank in the soil, since it was found that a reduction in the number of ploughings to three in the crop rotation decreased the seed bank, and it was the application of only one ploughing which clearly increased this trait compared to typical tillage ( 7 ploughings in the crop rotation). Such findings are only partially consistent with the results of Witk ow s ki (1998), C a r d in y et al. (1991), F eld man et al. (1992), P a p a et al. (1994), C ous ens and Moss (1990) as well as We s o łow s ki and B u jak (2006) in whose studies the application of tillage simplifications, mainly direct sowing, resulted in an increase in the weed seed bank. In turn, Wr z e s i ń s k a et al. (2004) as well as O p i c (1996) noted a decrease in the weed seed bank under the influence of no-plough tillage or the application of direct sowing. But D w o ř a k (1987) reports that a decrease in tillage depth in crop sequencing did not result in an increase of potential weed infestation.

In our study, no great difference was found in the number of weed diaspores in the analysed soil layers. But Wrzesińs k a et al. (2004), O p i c (1996), Orzech et al. (2006), Zawieja et al. (2000), Dorado et al. (1999), Unger et al. (1999) noted 


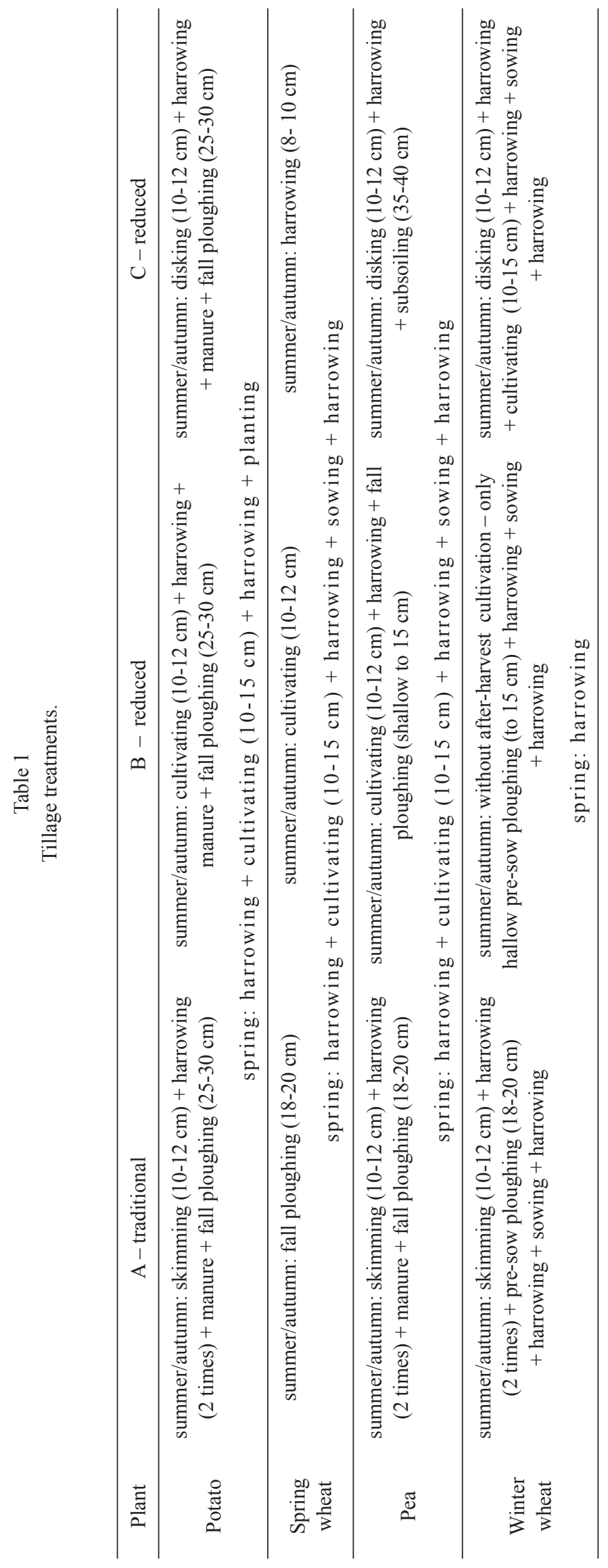




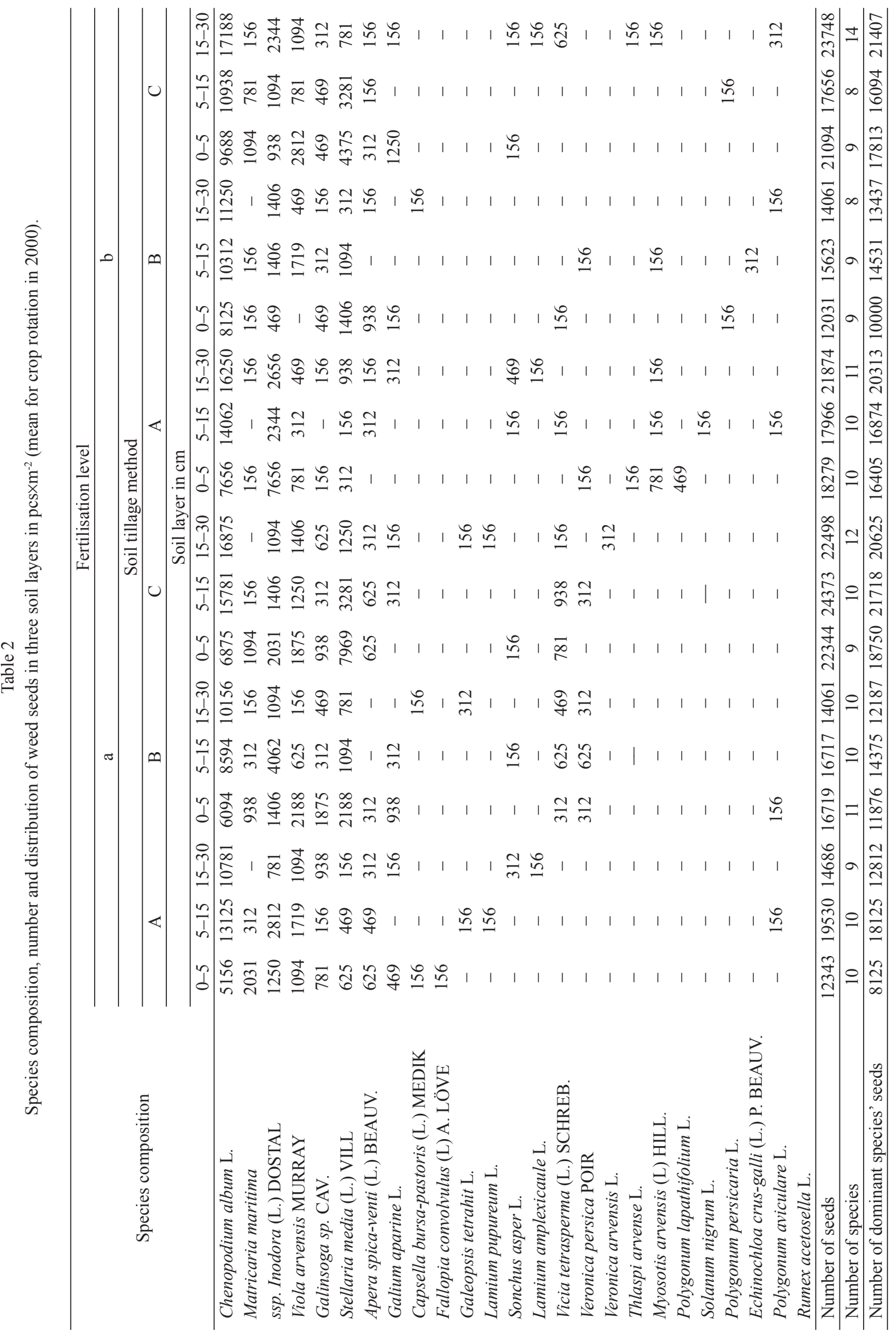




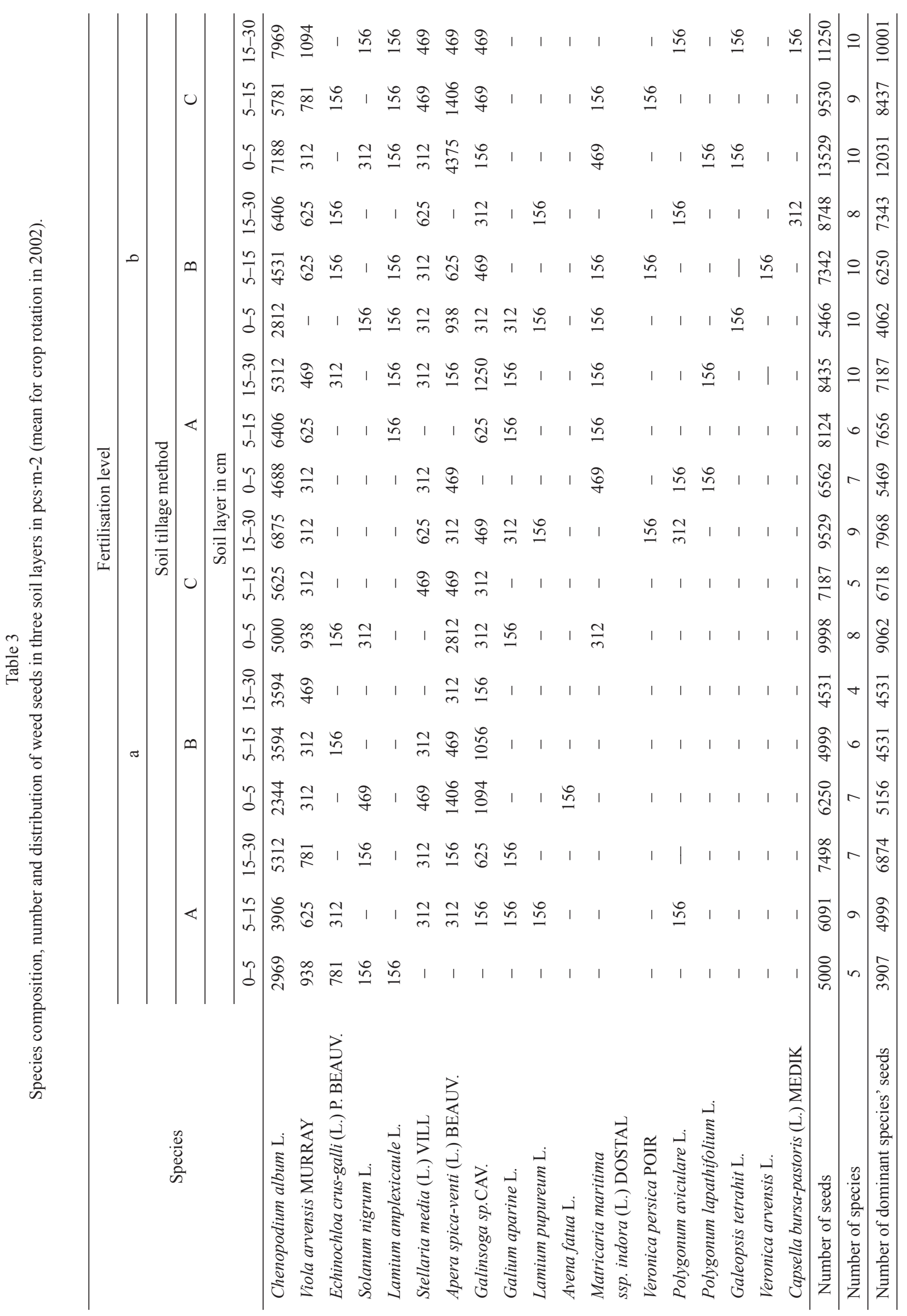


Table 4

Number of weed seeds in 0-30 $\mathrm{cm}$ soil layer in $\mathrm{pcs} \times \mathrm{m}^{-2}$ (mean per crop rotation).

\begin{tabular}{|c|c|c|c|c|c|c|c|}
\hline \multirow{2}{*}{$\begin{array}{l}\text { Soil tillage } \\
\text { method }\end{array}$} & \multirow{2}{*}{$\begin{array}{l}\quad \text { Weed seeds } \\
\text { 1. Total } \\
\text { 2. Dominant species }\end{array}$} & \multicolumn{2}{|c|}{ Fertilisation level } & \multirow[b]{2}{*}{ Mean } & \multicolumn{3}{|c|}{ Soil layer in $\mathrm{cm}$} \\
\hline & & $\mathrm{a}$ & $\mathrm{b}$ & & $0-5$ & $5-15$ & $15-30$ \\
\hline \multicolumn{8}{|c|}{2000} \\
\hline \multirow[t]{2}{*}{ A } & 1 & 46559 & 58119 & 52339 & 15311 & 18748 & 18280 \\
\hline & 2 & 39062 & 53592 & 46327 & 12265 & 17500 & 16562 \\
\hline \multirow[t]{2}{*}{ B } & 1 & 47497 & 41715 & 44606 & 14375 & 16170 & 14061 \\
\hline & 2 & 38438 & 37968 & 38203 & 10938 & 14453 & 12812 \\
\hline \multirow[t]{2}{*}{$\mathrm{C}$} & 1 & 69215 & 62498 & 65856 & 21719 & 21014 & 23123 \\
\hline & 2 & 61093 & 55314 & 58204 & 18282 & 18906 & 21016 \\
\hline \multirow[t]{2}{*}{ Mean } & 1 & 54424 & 54111 & 54267 & 17135 & 18644 & 18488 \\
\hline & 2 & 46198 & 48958 & 47578 & 13828 & 16953 & 16797 \\
\hline \multicolumn{8}{|c|}{$\begin{array}{l}\text { LSD }(p=0.05) \text { 1. total between: tillage methods }-3801 ; \\
\text { 2. dominant between: tillage methods }-4536\end{array}$} \\
\hline \multicolumn{8}{|c|}{2002} \\
\hline \multirow[t]{2}{*}{ A } & 1 & 18589 & 23121 & 20855 & 5781 & 7108 & 7966 \\
\hline & 2 & 15780 & 20312 & 18046 & 4688 & 6328 & 7030 \\
\hline \multirow[t]{2}{*}{$\mathrm{B}$} & 1 & 15780 & 21556 & 18668 & 5858 & 6170 & 6640 \\
\hline & 2 & 14218 & 17655 & 15936 & 4609 & 5390 & 5937 \\
\hline \multirow[t]{2}{*}{$\mathrm{C}$} & 1 & 26714 & 34372 & 30543 & 11795 & 8358 & 10390 \\
\hline & 2 & 23748 & 30469 & 27108 & 10546 & 7578 & 8984 \\
\hline \multirow[t]{3}{*}{ Mean } & 1 & 20361 & 26350 & 23355 & 7811 & 7212 & 8332 \\
\hline & 2 & 17915 & 22812 & 20363 & 6614 & 6432 & 7317 \\
\hline & $\begin{array}{r}\operatorname{LSD}(p=0.05) 1 \\
2\end{array}$ & $\begin{array}{l}1 \text { betwee } \\
\text { inant be }\end{array}$ & $\begin{array}{l}\text { ge metho } \\
\text { tillage } n\end{array}$ & $\begin{array}{l}900 \text {; fer } \\
s-183\end{array}$ & $\begin{array}{l}\text { n levels } \\
\text { isation } 1\end{array}$ & 1222 & \\
\hline
\end{tabular}

a significant increase in the number of weed seeds on the soil surface and a marked decrease in their number in the deeper layers under the influence of tillage simplifications, in particular the application of direct sowing.

The influence of the mineral fertilisation level was evident only in the second period of the study in which a significant increase in the seed bank in the soil was noted in the more intensively fertilised treatments. The absence of research in this area prevents a confrontation of results. The studies of K ę s i k (1980), B l e charczyk et al. (2000) as well as Pawłowski and Wesołowski (1990) demonstrate that more intensive fertilisation is one of factors inhibiting weed infestation of a crop canopy.

When analysing the species composition of weed seeds in the soil, it should be stated that it is typical for loess-formed soils (We s oło w s k i, 1986) and plants cultivated in a crop rotation system (K a p e l u s z n y and Jędruszczak, 1992). The dominant species were Chenopodium album, Viola arvensis, Apera spica-venti and Galinsoga sp, which accounted for over $80 \%$ of the total bank of weed diaspores. Similarly, B ochenek (1992), Radecki and Ciesielska (2000) also report that only several weed species are always predominant in weed communities found in the soil. A substantial decrease in the seed weed bank in the soil and a reduction in their species composition noted after the end of the rotation, compared to the first period of the study, resulted from the application of intensive chemical protection of canopies of particular plants. It finds confirmation in earlier studies of D wořak and Krejcir (1980), Roberts (1981), A d a m i a k et al. (1988) who report that the introduction of herbicides in the protection of crop canopies significantly reduces the weed seed pool in the soil and impoverishes the species composition of the community.

\section{CONCLUSIONS}

1. A comparison of results of determinations from the end of the crop rotation and its beginning showed that a very large decrease in the number of weed diaspores in the soil occurred in all the experimental treatments.

2. A reduction in the number of ploughings to three in the crop rotation decreased weed infestation of the plough layer, whereas giving only one ploughing clearly increased the weed diaspore bank in the soil compared to typical tillage. 
3. In the first period of the study, the mineral fertilisation level did not differentiate the weed seed bank in the soil. But there was its significant increase after the end of the rotation as a result of more intensive fertilisation.

4. Diaspores of Chenopodium album, Viola arvensis, Galinsoga sp. and Apera spica-venti occurred in greatest numbers in the examined loess soil layer.

\section{REFERENCES}

Adamiak E., Adamiak J., Pawluczuk J., 1988. Weeding of winter wheat in specialized crop rotations and monoculture. Acta Univ. Agric. Brno, Fac. Agron. 36 (2-4): 327-334.

Blecharczyk A., Małecka I., Skrzypczak G., 2000. Effect of Long-Term Fertilisation Crop Rotation and Continuous Cropping on Weed Infestation of Spring Barley. Ann. Univ. Mariae Curie-Skłodowska, sect. E, 55 (10): 17-23.

Bochenek A., 2000. Impact of biotic factors and cultivation treatment on weed seed bank in the soil. Post. Nauk. Roln. 2: 19-28.

Cardina M., Regnier E., Harrisom K. 1991. Long - term tillage effects on seed banks in three ohio soil. Weed Sci. 39: 186-194.

Cousens R., Moss S.R. 1990. Model of the Effects of Cultivation on the Vertical Distribution of Weed Seeds in the Soil. Weed Res. 30 (1): 61-70.

Dardo J., Del Monte J. P., Lopez-Fando C., 1999. Weed seed bank response to crop rotation and tillage in semiarid agroecosystems. Weed Sci. 47: 67-73.

Dwořak J., Krejcir J., 1980. Zasoba semen a plodu plevelu w ornici w podminkach rozdilnehostoidani plodin a aplikace herbicydu. Acta Univ. Agricult. (Brno), Fac. Agron. 28 (2): 2-9.

Dwořak J., 1987. Potencialni zapleveleni ornice w podminkach rozdilneho stridani plodin a hloubky zakladni kultivace pudy. Acta Acad. Agricult. Techn. Olst. Agricultura, 44: 171-179.

Dzienia S., Sosnowski A., 1991. Possibilities for application of direct sowing on good rye complex soil under the climatic conditions of western Pomerania. Rocz. Nauk. Roln. A, 109: 157-173.

Feldman S. R., Alzugary C., Torres P. S., Levis P., 1992. The effect of different tillage systems on the composition of the seedbank. Weed Res. 37: 71-76

Gawrońska-Kulesza A., 1997. Evolution of systems and methods of soil tillage. Zesz. Prob. Post. Nauk Rol. 439: 185-193.

Kapeluszny J., Jędruszczak M., 1992. Weed infestation of crop cereals in the configurated area on loess soils of Nałeczow Plateau. Zesz. Nauk AR Kraków, 33 (261): 187-195.

Kęsik T., 1980. Effect of some agronomic measures on weediness of rye cultivated on light soil. Zesz. Prob. Post. Nauk Rol. 227: 75-82.
Kordas L., 1999. Energy consumption and effectiveness tillage systems in crop rotation. Fol. Univ. Agric. Stetin. Agricultura, 74: 47-52.

Malicki L., Nowicki J., Szwejkowski Z., 1997. Soil and crop responses to soil tillage systems: a Polish perspective. Soil. Till. Res. 43: 65-80.

Mirek Z., Piękoś-Mirek H., Zając A., Zając M., 1995. Vascular Plants of Poland Checklist Polish botanical studies Guidebook Polish, series No 15, PAN Kraków.

Opic J., 1996. The influence of direct drilling and depth of ploughing on the number of weed seeds in soil. Rocz. Nauk Roln. A, 112 (1-2): 113-121.

Orzech K., Buczyński G., Markowski P., 2006. The influence of soil tillage simplifications on potential infestation of medium soil. Fragm. Agron. 23, 2 (90): 242250.

Pawłowski F., Wesołowski M., 1990. Level of agrotechnics versus yielding and weediness of crops cultivated in the crop rotation on loess soil. Rocz. Nauk Roln. A, 108 (3): 21-35.

Papay A. J., Cox T. J., Ingle A., Kerr R., 1994. Effects of soil disturbance on weed seedling emergence and its longterm decline. Weed Res. 34: 403-412.

Radecki A., 1986. Studies on applying of direct drilling system on the proper black soil. SGGW Warszawa: 1-86.

Radecki A., Ciesielska A., 2000. Weed infestation of canopy and soil production of rape plantation. Ann. Univ. Mariae Curie-Skłodowska, sect. E, Agricultura, 55: 161-166.

Roberts H. A., 1981. Seed banks in soil Adv. Apll. Biol. 6: $1-55$.

Skrzypczak G., Blecharczyk A., Pudełko J., Waniorek W., 1995. Influence of reduced soil tillage systems on weed infestation and yield of winter wheat. Mat. 35 Sesji IOR cz. 2: 367-369.

Unger P. W., Miller S. D., Jones O. R. 1999. Weed seeds in long-term dryland tillage and cropping system plots. Weed Res. 39: 213-222.

We sołowski M., 1986. Content of weed seeds in some important soils of sou the eastern and central Polands macroregions. Rocz. Nauk Roln. 106-A-1: 169-183.

We sołowski M., Bujak K., 2006. The influence of simplified on reserve of weeds in erodible loess soil. Acta Agrobot. 59 (2): 353- 363.

Witkowski F. 1998. The impact of long-term simplified soil cultivation on the number and distribution of weed seeds in soil. Post. Nauk Roln. 1: 31-40.

Wrzesińska E., Dzienia S., Wereszczaka J., 2004. Effect of different cultivation systems on the number and composition of weed seed bank. Fragm. Agron. 21, 2 (82): 52-60

Zawieja J., Wojciechowski W., Wacławowicz R., 2000. Influence of varying soil tillage on the number and vertical distribution of weed seeds in soil of the winter wheat monoculture. Ann. Univ. Mariae Curie-Skłodowska, Sect. E, Agricultura, 55: 239-244. 
Wpływ uproszczeń uprawy roli i poziomu nawożenia mineralnego na liczbę i rozmieszczenie nasion chwastów w glebie

\section{Streszczenie}

W pracy przedstawiono wyniki badań nad wpływem ograniczenia liczby orek w rotacji płodozmianu oraz poziomu nawożenia mineralnego na kształtowanie się zapasu nasion chwastów w glebie. Badania przeprowadzono $\mathrm{w}$ drugim i czwartym roku rotacji płodozmianu (ziemniak - pszenica jara - groch siewny - pszenica ozima). Ograniczenie liczby orek do trzech w rotacji płodozmianu zmniejszało zachwaszczenie warstwy ornej, a po wykonaniu tylko jednej orki było wyraźnie więcej diaspor chwastów w glebie niż po uprawie płużnej. Poziom nawożenia mineralnego w pierwszym terminie badań nie różnicował zapasu nasion chwastów w glebie, zaś po zakończeniu rotacji odnotowano znaczny jego wzrost w wyniku intensywniejszego nawożenia. Na wszystkich obiektach doświadczenia najliczniej występowały diaspory: Chenopodium album, Viola arvensis, Galinsoga sp. i Apera spica-venti. 